\title{
Molecular characterization of Turnip yellows virus - a new pathogen of mustards in Serbia
}

\author{
Dragana Milošević ${ }^{1 *}$. Maja Ignjatov ${ }^{1}$. Ana Marjanović Jeromela ${ }^{1}$ Ivana Stanković ${ }^{2}$ \\ Zorica Nikolić ${ }^{1}$ Gordana Tamindžić ${ }^{1}$. Branka Krstićc
}

${ }^{1}$ Institute of Field and Vegetable Crops, Maksima Gorkog 30, 21000 Novi Sad, Serbia

2University of Belgrade, Faculty of Agriculture, Institute of Phytomedicine, Nemanjina 6, 11080 Belgrade, Serbia

\begin{abstract}
Summary: In 2018, a total of 58 mustard samples from two different localities in Serbia (Rimski Šančevi and Senta) were collected and tested for the presence of Turnip yellow virus ( $\mathrm{TuYV}$ ), Cauliflower mosaic virus (CaMV) and Turnip mosaic virus (TuMV) by DAS-ELISA. TuYV was serologically detected in 42 tested samples while all collected samples were negative for CaMV and TuMV. By using aphid transmission tests, five test plants were inoculated with two ELISApositive TuYV samples of naturally infected mustard plants. Virus species identification was performed by amplification of a $780 \mathrm{bp}$ fragment in all tested samples using the specific primers TuYVorf0F/TuYVorf0R. The RTPCR products from two isolates 88Sal (MK144816) and 98Bni (MK144817) were sequenced and compared with the GenBank sequences of TuYV. Serbian isolates showed the highest identity with Poland TuYV isolate (EU022489). Phylogenetic analysis showed that TuYV isolates from Serbia were clustered with other TuYV sequences retrieved from the GenBank.

Key words: DAS-ELISA, mustards, phylogenetic analysis, RT-PCR, Turnip yellows virus
\end{abstract}

\section{Introduction}

Mustard plant species belong to the genus Brassica and Sinapis of the Brassicaceae family. The most common species are pale yellow or white mustard (Sinapis alba) and black or brown mustard (Brassica nigra). Mustard plant originates from the region around the Mediterranean Sea and the Middle East. Now it can be found all over the world as cultivated species and weeds. It is well known for its condimental, therapeutic and flavouring properties (Sharma et al., 2018). Mustard leaves are regarded as a vegetable, while the seeds can be used as a condiment and constitute the source of mustard oil (Manohar et al., 2009).

A number of viruses such as Beet western yellow virus (BWYV), Cauliflower mosaic virus (CaMV), and Turnip mosaic virus (TuMV) can infect Brassica crops (Farzadfar

Corresponding author:

dragana.milosevic@ifvcns.ns.ac.rs

Acknowledgement:

This research was supported by the Ministry of Education, Science and Technological Development, Republic of Serbia, under the Projects TR 31025 , TR 31030 and III 43001

Cite this article:

Milošević D., Ionjatov M., Marjanović Jeromela A., Stanković I., Nikolić Z., Tamindžić G., Krstić B. (2019). Molecular characterization of Turnip yellows virus new pathogen of mustards in Serbia. Ratar: Pourt., 56 (3), 82-87. et al., 2007). BWYV was originally detected in the USA in the late 1950s and it was reported that it caused different symptoms in a number plant species, such as stunting and chlorosis, and it also resulted in yield losses in sugar beet, spinach, turnip, and lettuce (Duffus, 1961; Duffus, 1977). The International Committee for the Taxonomy of Viruses (ICTV) has re-classified many of the isolates previously named as BWYV, which have not been proved to infect sugar beet (Beta vulgaris L.), as an independent species within the genus Polerovirus, as Turnip yellows virus (TuYV) (Mayo, 2002).

TuYV causes harmful diseases in many species of Brassica and other crops worldwide, including economically important vegetable, oilseed, forage, tobacco and ornamental crops (Jay et al., 1999; Sharma et al., 2013; Wang et al., 2015; Farzadfar et al., 2007). The wide range of cultivated plants, as well as a variety of weed species susceptible to TuYV, extend the range of potential reservoir hosts where the virus can successfully overwinter and provide an inoculum source for future viral infectious (Latham et al., 2003). TuYV is transmitted by a few aphid species in a persistent manner, with the green-peach aphid, Myzus persicae as the main vector (Hauser et al., 2002).

Considering that TuYV is one of the most important and widespread viruses in brassica crops worldwide, the virus presence in oilseed rape crop in Serbia (Milošević et al., 2015), as well as the common 
presence of a lot of aphids known as virus vectors, TuYV potentially represents a limiting factor for a successful production of mustard plants in Serbia. Moreover, virus-like symptoms are increasingly noticed in the production of mustards in Serbia. The main objectives of this study were to identify the virus presence in other Brassica species in Serbia and to study their taxonomic position based on sequencing of P0 gene.

\section{Material and Methods}

Sample collection

In 2018, mustard leaf samples showing virus-like symptoms, including mild reddening of leaf margins followed by mild yellowing leaves, were collected from two crops at two different localities: Rimski Šančevi (South Bačka District) and Senta (North Banat District) in Serbia. A total of 33 symptomatic Sinapis alba plants (10 samples from Rimski Šančevi and 23 from Senta locality) and 25 Brassica nigra plants (10 samples from Rimski Šančevi and 15 from Senta locality) were collected. The samples were transported in plastic bags, and stored at $4^{\circ} \mathrm{C}$ until ELISA test was performed or at $-20^{\circ} \mathrm{C}$ until RNA extraction and RT-PCR analysis were performed.

\section{Serological detection}

All 58 collected samples were tested using doubleantibody sandwich enzyme-linked immunosorbent assay (DAS-ELISA) according to manufacturer's instructions (Loewe Biochemica, Germany) specific for detection of three most frequent viruses on Brassica species: Turnip yellow virus (TuYV), Cauliflower mosaic virus (CaMV) and
Turnip mosaic virus (TuMV) (Nooh, 2012). Fresh leaves of plant samples were ground in extraction buffer (1:10 $\mathrm{wt} / \mathrm{vol}$ ). The commercial positive and negative controls (as well as the extracts from the healthy mustard leaf tissue) for the above-mentioned viruses, were included in each ELISA test. After incubation with p-nitrophenyl phosphate (Sigma-Aldrich, USA), absorbance values were determined at $405 \mathrm{~nm}$ (A405) by an ELISA microplate reader (Multiscan Ascent, Finland). Samples were considered positive if the average optical density (OD) was twice higher than the average OD of the negative control.

\section{Aphid transmission}

Myzus persicae (Sulzer) was used as a vector in aphid transmission test of the selected TuYV isolates from both localities. Nymphs were allowed to feed on the leaves of the two selected ELISA positive samples (88Sal and 98Bni), one sample per each host, for $24 \mathrm{~h}$ (Acquisition access period, AAP). Two groups of 6-8 aphids were thereafter transferred onto ten plants of each Beta vulgaris, Physalis floridana, Brassica napus 'Zlatna', $S$. alba and $B$. nigra for an inoculation access period (IAP) of 4-day. The plants and aphids were put into small cages, placed in acclimatized room with a $16 \mathrm{~h}$ photoperiod at $22^{\circ} \mathrm{C}$. After this inoculation access period, aphids were removed. After 5 weeks, the presence of virus in inoculated plants was assessed using DAS-ELISA, with commercial kit for TuYV.

\section{Molecular detection and sequence analysis}

Four selected samples were analysed by conventional Reverse Transcription Polymerase Chain Reaction (RT-PCR) to confirm the DAS-ELISA results.

Table 1. Sequences of Turnip yellows virus, Beet western yellows virus, Beet chlorosis virus, Cereal yellow dwarf virus and Cucurbit aphid-borne yellows virus isolates used in the phylogenetic analysis

\begin{tabular}{|c|c|c|c|c|}
\hline Virus & Isolate name & Country & Host plant & GenBank Acc. No. \\
\hline TuYV & 88Sal & Serbia & Sinapis alba & MK144816 \\
\hline TuYV & 98Bni & Serbia & Brasica nigra & MK144817 \\
\hline TuYV & 119-TuYV & Serbia & Oilseed rape & KU351664 \\
\hline TuYV & 114-TuYV & Serbia & Oilseed rape & KR351306 \\
\hline TuYV & FL1 & France & Lactuca sativa & NC003743 \\
\hline TuYV & TuYV-BN5 & Germany & Oilseed rape & AF168606 \\
\hline TuYV & TuYV-GB & England & Oilseed rape & AF168608 \\
\hline TuYV & TuYV-FL1 & France & Lactuca sativa & X13063 \\
\hline $\mathrm{BChV}$ & BChV-CR & USA & Sugar beet & AF352025 \\
\hline BChV & BChV-GW & California & Sugar beet & AF167485 \\
\hline $\mathrm{BChV}$ & $\mathrm{BChV}-2 \mathrm{a}$ & England & - & NC002766 \\
\hline CYDV-RPS & NY & - & - & NC004751 \\
\hline CYDV-RPV & CYDV-RPS & - & - & NC002198 \\
\hline BWYV & USA & USA & Sugar beet & AF473561 \\
\hline BWYV & BJ-B & China & Sugar beet & HM804472 \\
\hline BWYV & $B J-A$ & China & Sugar beet & HM804471 \\
\hline BWYV & USA & - & - & NC004756 \\
\hline CabYV & $\mathrm{N}$ & France & Cucurbit & X76931 \\
\hline CabYV & Xinjiang & China & Cucumis melo & EU636992 \\
\hline CabYV & Beijing & China & Cucurbit & EU000535 \\
\hline CabYV & $\mathrm{N}$ & France & - & NC003688 \\
\hline
\end{tabular}


Total RNA was isolated using RNeasy Plant Mini Kit (Qiagen, Hilden, Germany) from $100 \mathrm{mg}$ of freeze-dried leaves of symptomatic plants. RT-PCR was carried out using the Qiagen One-Step RT-PCR Kit with specific TuYV primers, TuYVorfOF/TuYVorfOR (Schubert et al., 1998) which flank P0 gene. The Serbian isolate of TuYV of oilseed rape (GenBank Accession No. KR351306) was used as positive control, while a tissue sample of healthy mustard leaf served as negative control. The RT-PCR reaction mixture included $400 \mu \mathrm{M}$ each of the four dNTPs, $1 \mu$ l of RT-PCR enzyme mix, $0.6 \mu \mathrm{M}$ each primer, and $1 \mu \mathrm{l}$ extracted RNA in a final volume of $25 \mu \mathrm{l}$. Amplifications were carried out in an Eppendorf Mastercycler Gradient (Eppendorf, Germany) under the following program: $30 \mathrm{~min}$ at $50^{\circ} \mathrm{C}$ for reverse transcription, $15 \mathrm{~min}$ at $95^{\circ} \mathrm{C}$ for initial PCR denaturation step, followed by 35 cycles of $30 \mathrm{~s}$ at $94^{\circ} \mathrm{C}$ for denaturation, $30 \mathrm{~s}$ at $55^{\circ} \mathrm{C}$ for annealing, $60 \mathrm{~s}$ at $72^{\circ} \mathrm{C}$ for primer extension and $10 \mathrm{~min}$ at $72^{\circ} \mathrm{C}$ for final extension.

The amplified fragments were analysed using electrophoresis on $1 \%$ agarose gel containing ethidium bromide $(0.5 \mathrm{~g} / \mathrm{mL})$ and visualized using UV transilluminator. The sizes of the amplified fragments were estimated by comparison with FastRuler DNA Ladder, Low Range (Fermentas, Lithuania).

The amplified products from two selected isolates 88Sal from $S$. alba and 98Bni from B. nigra were sequenced in both directions (Macrogen, Korea), with primers used for its detection. The nucleotide sequences of the isolates were deposited in GenBank database (http://www.ncbi.nlm.nih.gov) and were compared with each other by calculating nucleotide (nt) and deduced amino acid (aa) identities, as well as with sequences deposited in the GenBank, using the ClustalW program (Thompson et al. 1994) and MEGA5 software (Tamura et al. 2011). A p-distance model was applied for nucleotide (nt) and deduced amino acid (aa) sequence analyses.

The phylogenetic tree was constructed using maximum parsimony method implemented in MEGA 5.0 based on two P0 gene sequences of TuYV obtained in this study, and sequences of TuYV, Beet western yellows virus (BWYV), Beet chlorosis virus (BChV), Cereal yellow dwarf virus (CYDV) and Cucurbit aphid-borne yellows virus (CabYV) isolates available in the GenBank. Genetic diversity intra and inter group of host and geographical origin were calculated with Kimura 2-parameter $(\mathrm{K} 2+\mathrm{G})$ which was chosen as the best-fitting model of nt substitution.

\section{Results and Discussion}

Prior to our study, there were no data on the prevalence and diversity of viruses in mustard grown in Serbia. In this study, the presence of TuYV was studied in two Brassica species, Brassica nigra and Sinapis alba.
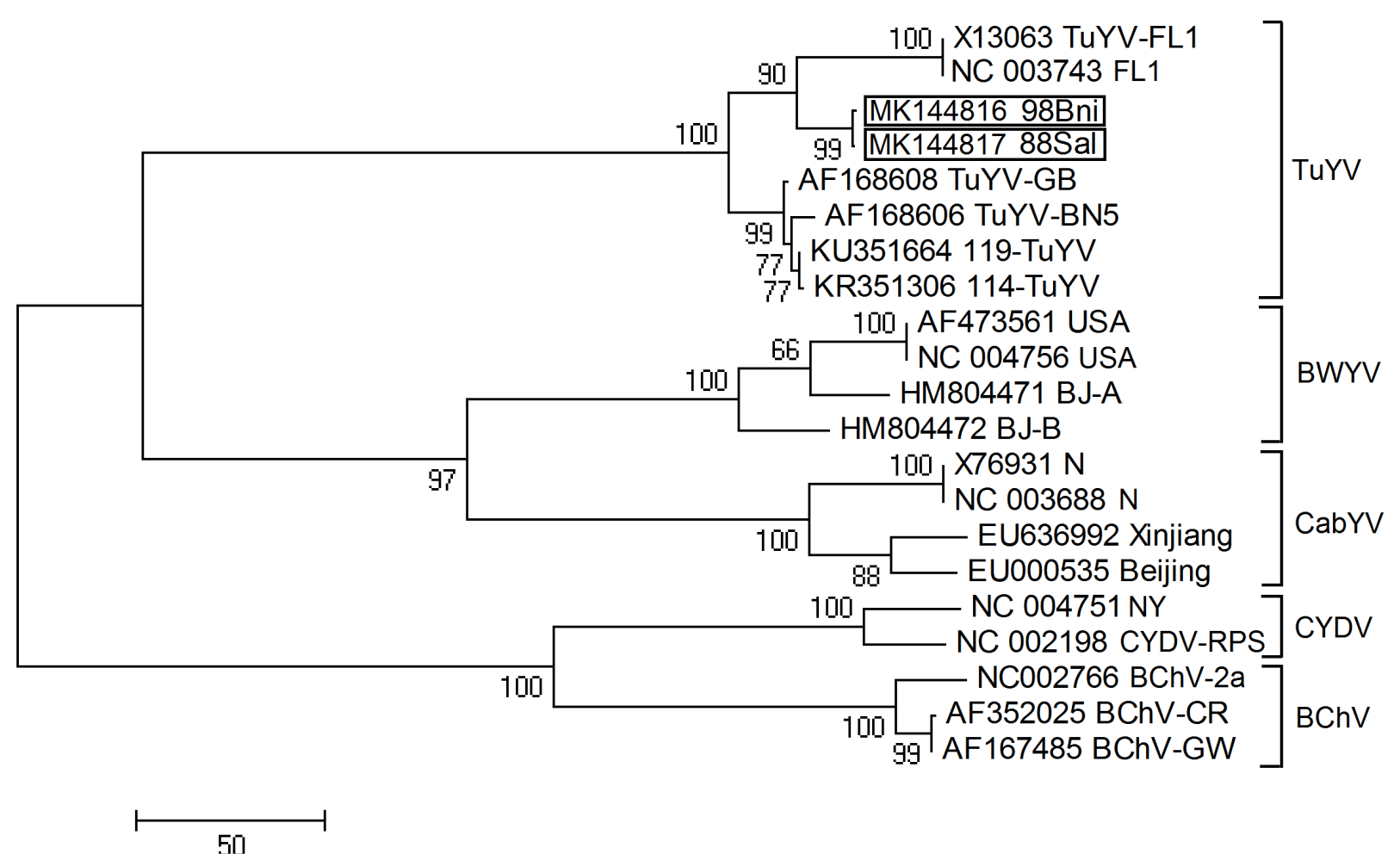

Figure 1. Maximum parsimony tree based on partial sequences of P0 gene of Turnip yellows virus, Beet western yellows virus, Beet chlorosis virus, Cereal yellow dwarf virus and Cucurbit aphid-borne yellows virus isolates. Phylogram was generated with MEGA5 using bootstrap analysis with 1000 replicates and bootstrap values $(>50 \%)$ are shown next to relevant branches. The Turnip yellows virus isolates from this study are framed. 
Serological detection and symptomatology in the field

During the observation of mustard fields in two localities in 2018, similar symptoms were noticed in both surveyed localities and disease incidence was estimated at 30\% and 50\%, respectively. Mild reddening of leaf margins followed by mild yellowing leaves were the most frequent symptoms.

Serological analysis of mustard samples showed the presence of TuYV in two localities in Serbia (Rimski Śančevi and Senta). TuYV was detected in 42 (72.4\%) of the tested samples collected during the survey and tested by DAS-ELISA. CaMV and TuMV were not found in the analysed mustard samples.

The presence of TuYV on $S$. alba was higher in Senta where $78.3 \%$ samples tested positive, compared to its presence in Rimski Šančevi where 50\% samples tested positive. Presence of TuYV on B. nigra showed similar results. The presence of TuYV on $B$. nigra was identified on $86.7 \%$ tested samples collected in Senta, while its presence in Rimski Šančevi was detected in $60 \%$ tested samples.

In some symptomatic samples, the analysed viruses were not discovered. It is more likely that other viruses infect brassica plants in Serbia, as previously reported (Farzadfar et al., 2005a; Farzadfar et al., 2005b; Shahraeen et al., 2003). Using the same method during 1998-2000, the frequency of occurrence of six viruses was determined in B. nigra collected from five coastal sites in Dorset (Thurston et al., 2001). Our study showed a higher frequency of TuYV in $B$. nigra compared to B. oleracea (43\%) reported by Raybould et al. (1999). The abundance and movement of the aphid vectors, mainly Myzus persicae and Brevicoryne brassicae can cause the spread of TuYV in different surveyed regions (Afshariazad, 2001; Sohani et al., 2002). This study reports the natural occurrence of TuYV on B. nigra and S. alba in Serbia for the first time.

\section{Aphid transmission}

After about 5 weeks post-inoculation, all inoculated $P$. floridana plants manifested a very mild interveinal chlorosis, while all inoculated B. napus 'Zlatna' plants showed mild leaf reddening. In addition, the virus was successfully transmitted to $S$. alba and $B$. nigra that reacted with a mild reddening of leaf margins and yellowing. No symptoms were observed in Beta vulgaris plants. All inoculated plants of each species (except plants of $B$. vulgaris) were tested positive for TuYV.

Based on previous studies, B. vulgaris, P. floridana, and B. napus could be used as test plants in order to make distinction Beet mild yellowing virus (BMYV) from BWYV European isolates (reclassified as TuYV) (Hauser et al., 2000). The results of host range studies showed that Serbian TuYV isolates could infect different Brassica species, but not B. vulgaris. These results correspond with those previously reported by other researchers (Stevens et al., 1994; Hauser et al., 2000).
Molecular detection and sequence identity analyses

The TuYVorfoF and TuYVorfOR primers specifically amplified target cDNA fragments of $780 \mathrm{bp}$ predict size and successfully detected the presence of TuYV in all four ELISA-positive samples as well as in positive control. No reaction was recorded in healthy mustard control.

The identities of the obtained products from selected isolates $88 \mathrm{Sal}$ and $98 \mathrm{Bni}$ were directly sequenced in both directions, after purification. The sequences of $S$. alba and B. nigra virus isolate in this study were submitted to the GenBank (MK144816 and MK144817, respectively). Sequence analysis of the of P0 gene revealed high nt identity of $99.8 \%(100 \%$ aa identity) among Serbian TuYV isolates from mustard. The Serbian isolates from mustard (88Sal and 98Bni) showed the highest nucleotide identity $(98.9 \%$ and $99 \%$, respectively) and amino acid identity (100\%) with a Poland TuYV isolate (EU022489). As indicated by King et al. (2011), the species demarcation criteria for the genus Polerovirus include differences in amino acid sequence identity of any gene product greater than $10 \%$, nucleotide identities showed that Serbian isolates belong to TuYV.

A Maximum parsimony tree (Fig. 1), reconstructed using the partial sequences of the P0 gene, showed that the TuYV isolates from this study and 19 representative isolates of previously characterized viruses within Polerovirus genus (TuYV, BWYV, CabYV, CYDV, and $\mathrm{BChV}$ ) from GenBank, were clustered into five groups. Genetic diversity among five groups of isolates ranged from $0.476 \pm 0.037$ to $2.514 \pm 1.122$, whereas within each group and subgroup the genetic diversity was: $0.087 \pm 0.009 \quad$ (TuYV), $0.095 \pm 0.011 \quad$ (BWYV), $0.108 \pm 0.012$ (CabYV), 0.093 \pm 0.013 (CYDV), and $0.037 \pm 0.007(\mathrm{BChV})$. The Serbian TuYV isolates $88 \mathrm{Sal}$ and $98 \mathrm{Bni}$ were clustered within the cluster with other TuYV isolates from the GenBank and were distinct from the BWYV isolates.

On the basis of high attack on other species of the family Brassicaceae, numerous weeds in growing regions throughout the world, and distinct yield losses determined in field experiments, the control of the infestation of Brassicaceae family by TuYV is deemed necessary. Further research is needed to detect the span of this virus and inoculum sources in nature.

\section{Conclusions}

To the best of our knowledge, this is the first report of the TuYV presence on Sinapis alba and Brassica nigra in Serbia. TuYV presence was confirmed by DASELISA tests and RT-PCR with specific primers. It is also the first report that confirmed the association of the symptoms of leaf yellowing and reddening and the TuYV in these species. Considering the rapid growth of mustard production in Serbia, the occurrence of TuYV 
could prevent its successful production. As TuYV can be found on various crops and easily transmitted in a non-persistent manner by aphids and a wide range of hosts, continuous monitoring of TuYV status and its presence in Serbia is necessary.

\section{References}

Afshariazad, H. (2001). Important diseases of oilseed rape. Publication series No. 21. Tehran, Iran: Agricultural Research, Education and Extension Organization (AREEO), Ministry of Jihad-EAgriculture.

Duffus, J. E. (1961). Economic significance of Beet western yellows (Radish yellows) on sugar beet. Phytopathology, 51, 605-607.

Duffus, J. E. (1977). Aphids, viruses, and the yellow plague. In: Harris, K.F., Maramorosch, K. (Eds.). Aphids as virus vectors (pp 361-383). New York: Academic Press.

Farzadfar, Sh., Ohshima, K., Pourrahim, R., Golnaraghi, A.R. Jalali S., \& Ahoonmanesh, A. (2005a). Occurrence of Turnip mosaic virus on ornamental crops in Iran. Plant Pathology, 54, 261 $-261$.

Farzadfar, Sh., Ohshima, K., Pourrahim, R., Golnaraghi, A.R., Jalali S., \& Ahoonmanesh, A. (2005b). Reservoir weed hosts for Turnip mosaic virus in Iran. Plant Disease, 89, 339-339.

Farzadfar, S., Ahoonmanesh, A., Hossein Mosahebi, G., Pourrahim, R., \& Reza Golnaraghi, A. (2007). Occurrence and distribution of Cauloflower mosaic virus on Cruciferous plant in Iran. Plant Pathology Journal, 6(1), 22-29.

Hauser, S., Stevens, M., Mougel, C., Smith, H.G., Fritsch, C., Herrbach, E. \& Lemaire O. (2000). Biological, serological and molecular variability suggest three distinct Polerovirus species infecting beet or rape. Phytopathology, 90(5), 460- 466.

Hauser, S., Stevens, M. Beuve, M., \& Lemaire, O. (2002): Biological properties and molecular characterization of beet chlorosis virus (BChV). Archives of Virology, 147, 745-762.

Jay, C.N., Rossall, S., \& Smith, H.G. (1999). Effects of Beet western yellows virus on growth and yield of oilseed rape (Brassica napus). Journal of Agricultural Science, 133, 131-139.

King, A.M.Q., Adams, M.J., Carstens, E.B., \& Lefkowitz, E.J. (2011). Virus Taxonomy: Ninth report of the International Committee on Taxonomy of Viruses. San Diego, CA: Elsevier Academic Press.

Latham, L.J., Smith, L.J., \& Jones, R.A.C. (2003). Incidence of three viruses in vegetable brassica plantings and associated wild radish weeds in south-west Australia. Australasian Plant Pathology, 32, 387-391.

Manohar, P.R., Pushpan, R., \& Rohini, S. (2009). Mustard and its uses in Ayurveda. Indian Journal of Traditional Knowledge, 8(3), 400-404.

Mayo, M.A. (2002). ICTV at the Paris ICV: results of the plenary session and the binomial ballot. Archives of Virology, 147, 22542260.

Milošević, D., Marjanović-Jeromela, A., Ignjatov, M., Jovičić, D., Stanković, I., Bulajić A., \& Krstić B. (2015). First Report of Turnip yellows virus on Oilseed Rape in Serbia. Plant Disease, 99(12), 1869

Raybould, A.F., Maskell, L.C., Edwards, M.L., Cooper, J.I., \& Gray, A.J. (1999). The prevalence and spatial distribution of viruses in natural populations of Brassica oleracea. New Phytologist, 141, 265-275.

Schubert, J., Rabenstein, F., Graichen, K., \& Richter, K. (1998). Comparison of the 5 '-end nucleotide sequences of luteoviruses from oilseed rape and sugar beet. Archives of Phytopathology and Plant Protection, 3, 519-530.

Shahraeen, N., Farzadfar, Sh., \& Lesemann, D.E. (2003). Incidence of viruses infecting winter oilseed rape (Brassica napus ssp. oleifera) in Iran. Journal of Phytopathology, 151, 614-616.

Sharma, L., Gupta, V. Ajmera P., \& Kumari S. (2018). Benefits of Brassica alba (mustard seeds) in managing metabolic disorders. Asian Journal of Science and Technology, 09 (04), 7925-7929.
Sharma, P., Verma, R.K., Mishra, R., Choudhary, D.K., \& Gaur R.K. (2013). First report of Turnip yellow virus (TuYV) in Brassica juncea (Indian mustard) in India. New Disease Reports, $27,21$.

Sohani, N.Z., Nejadian, I.S., \& Mohseni, A.A. (2002). Biology of cabbage aphid B. brassicae (Hom. Aphididae) on four rape seed varieties in laboratory conditions. In Proceedings of the 15th Iranian Plant Protection Congress (pp. 58). Kermanshah, Iran: Razi University of Kermanshah.

Stevens, M., Smith, H.G., \& Hallsworth, P.B. (1994). The hostrange of Beet yellowing viruses among common arable weed species. Plant Pathology, 43, 579-588.

Tamura, K., Peterson, D., Peterson, N., Stecher, G., Nei, M. \& Kumar, S. (2011): MEGA5: molecular evolutionary genetics analysis using maximum likelihood, evolutionary distance, and maximum parsimony methods. Molecular Biology and Evolution, 28, 2731-2739.

Thompson, J.D., Higgins, D.G., \& Gibson, T.J. (1994). CLUSTAL W: Im-proving the sensitivity of progressive multiple sequence alignment through sequence weighting, positionspecific gap penalties and weight matrix choice. Nucleic Acids Research, 22, 4673-4680.

Thurston, M.I., Pallett, D.W., Cortina-Borja, M., Edwards, ML., Aybould, A.F.; \& Cooper, J.I. (2001). The incidence of viruses in wild Brassica nigra in Dorset (UK). Annals of Applied Biology, 139, 277-284.

Wang, F., Wu Q.F., Zhou, B.G. Gao, Z.L. \& Xu, D.F. (2015) First Report of Turnip yellows virus in Tobacco in China. Plant Disease, 99 (12): 1870. 


\section{Molekularna karakterizacija Turnip yellows virus - novog patogena slačice u Srbiji}

\section{Dragana Milošević · Maja Ignjatov · Ana Marjanović Jeromela · Ivana Stanković · Zorica Nikolić · Gordana Tamindžić · Branka Krstić}

Sažetak: : Tokom 2018. godine, sa dva lokaliteta gajenja slačice, ukupno je sakupljeno 58 uzoraka koji su serološki testirani na prisustvo Turnip yellow virus (TuYV), Cauliflower mosaic virus (CaMV) i Turnip mosaic virus (TuMV) korišćenjem komercijalno dostupnih kitova za DAS-ELISA test. Prisustvo TuYV serološki je dokazano u 42 sakupljena uzorka slačice, dok prisustvo CaMV i TuMV nije dokazano ni u jednom od testiranih uzoraka. Za dalja istraživanja odabrana su dva izolata TuYV prirodno zaraženih biljaka slačice, koji su uspešno preneti vašima na pet različitih test biljaka, čime je potvrđena infektivna priroda oboljenja. Molekularna detekcija obavljena je amplifikacijom fragmenta dužine 780 bp kod četiri ispitivana izolata korišćenjem specifičnih prajmera TuYVorf0F i TuYVorf0R. RT-PCR produkti izolata 88Sal i 98Bni su sekvencirani (MK144816 i MK144817) i upoređeni sa TuYV sekvencama dostupnim u GenBank bazi podataka. Izolati iz Srbije su pokazali najviši stepen nukleotidne sličnosti od 98,9\% i 99\% (100\% aminokiselinska sličnost) sa izolatom TuYV Br iz Poljske (EU022489). Filogenetska analiza pokazala je grupisanje TuYV izolata iz Srbije zajedno sa ostalim TuYV izolatima iz GenBank baze podataka. Ključne reči: DAS-ELISA, filogenetska analiza, RT-PCR, slačica, Turnip yellows virus 